\title{
Antimicrobial activity of chitosan against vibrios from freshwater prawn Macrobrachium rosenbergii larval rearing systems
}

\author{
A. Anas ${ }^{1}$, S. Paul ${ }^{1}$, N. S. Jayaprakash ${ }^{1,3}$, R. Philip ${ }^{2}$, I. S. Bright Singh ${ }^{1, *}$ \\ ${ }^{1}$ Centre for Fish Disease Diagnosis and Management (CFDDM), and ${ }^{2}$ Department of Marine Biology Microbiology and \\ Biochemistry, Cochin University of Science and Technology (CUSAT), Kochi 682 016, Kerala, India \\ ${ }^{3}$ Present address: Centre for Bioseparation Technology, Vellore Institute of Technology, Vellore 632 014, \\ Tamil Nadu, India
}

\begin{abstract}
Chitosan is a biocompatible and biodegradable natural polymer with established antimicrobial properties against specific microorganisms. The present study demonstrates its antibacterial activity against 48 isolates of Vibrio species from prawn larval rearing systems. The antibacterial activity had a positive correlation with the concentration of chitosan. This work opens up avenues for using chitosan as a prophylactic biopolymer for protecting prawn larvae from vibriosis.
\end{abstract}

KEY WORDS: Vibriosis · Chitosan · Macrobrachium rosenbergii · Antimicrobial

\section{INTRODUCTION}

Chitosan is a cationic polysaccharide derived from chitin, a natural polymer of $\mathrm{N}$-acetyl glucosamine commonly found in crustacean and insect exoskeletons, and in fungal cell walls (Shepherd et al. 1997). It is a biocompatible and biodegradable natural polymers and has interesting biological activity (Akbuga 1995). There are several reports on the anti-microbial activity of chitosan against several species of bacteria, yeasts and fungi (Allan \& Hadwiger 1979, Kendra \& Hadwiger 1984, Sudarshan et al. 1992, Wang 1992, Roller \& Covill 1999, Zheng \& Zhu 2003). It has been suggested that its antibacterial effect is based on its ability to increase permeability of the outer membrane of Gram-negative bacteria (Sudarshan et al. 1992, Chirkov 2002). In addition, it has wound healing properties, and has been used in cosmetics, drug delivery, food protection, and as an immunostimulant (Sahoo \& Mukergee 1999, Ravi Kumar 2000). However, its application for disease management in aquaculture has not been considered.
The present study describes the antimicrobial activity of chitosan against 48 isolates of Vibrio spp. from Macrobrachium rosenbergii larval rearing systems. In India, 71 freshwater prawn hatcheries currently under operation have a production capacity of 1.83 billion post larvae (Bojan 2003), but larval production technology has not yet been perfected. One problem is recurrent vibriosis (Sindermann 1977), which reduces larval survival below the level of economic viability. Therefore, management of vibriosis is of great concern in prawn hatchery systems. In general, Vibrio spp. are prevalent on eggs, larvae and post larvae of $M$. rosenbergii (Bhat \& Singh 1999), and their increase in number during culture operations is a serious problem (Delves-Broughton \& Poupard 1976, Takahashi et al. 1985).

The use of antibiotics to control vibriosis in shrimp/ prawn hatcheries has been documented (Karunasagar et al. 1994). However, prophylactic use of antibiotics can lead to the emergence of antibiotic-resistant bacteria (Tendencia \& de la Pena 2001). Therefore, the industry needs alternative strategies to combat vibrio- 
sis with minimal negative environmental impact. It was in this context that chitosan was considered as a possible prophylactic agent.

\section{MATERIALS AND METHODS}

Chitosan. Chitosan used in this study was obtained from M/s South India Sea Foods, Kochi, Kerala, India. It was extracted from crustacean exoskeletons, had an average molecular weight of $180 \mathrm{kDa}$ and was $80 \%$ de-acetylated. Different concentrations of chitosan $(0.25,0.5,0.75$ and $1.0 \%)$ were prepared by dissolving in $50 \mathrm{ml} 5 \%$ glacial acetic acid (v/v) (Kubota 1993) up to $100 \mathrm{ml}$ using distilled water. The $\mathrm{pH}$ was adjusted to 5.5-6.0 using $1 \mathrm{~N} \mathrm{NaOH}$.

Vibrio. The 48 isolates of vibrios used in this study were taken from the culture collection of the Centre for Fish Disease Diagnosis and Management, Cochin University of Science and Technology Kochi, Kerala, India. These isolates were accumulated over time from freshwater prawn larval rearing systems, and characterized phenotypically. All the isolates were grown in ZoBell's Marine Broth (2216E) prepared in 15 ppt salinity seawater for 12 to $15 \mathrm{~h}$ on a rotary shaker at $100 \mathrm{rpm}$. They were harvested at the exponential phase of growth, diluted to $10^{-6}$, and used for assaying the antibacterial properties of chitosan.

Antibacterial assay. Antibacterial activity was measured following the method of Zheng \& Zhu (2003) with slight modification. Briefly, ZoBell's Marine Agar (2216E) plates were prepared using 15 ppt seawater. Then $100 \mu \mathrm{l}$ Vibrio suspension was spread on the plates followed by $100 \mu \mathrm{l}$ of chitosan preparation in $5 \%$ glacial acetic acid (pH 5.5 to 6.0). Controls were identical except that $100 \mu \mathrm{l}$ of acetic acid solution $(\mathrm{pH} 5.5$ to 6.0) replaced the chitosan solution. All plates were incubated at $28 \pm 1^{\circ} \mathrm{C}$ for $24 \mathrm{~h}$ before the total number of colonies was enumerated. Inhibition rate $(\eta)$ was calculated using the equation:

$$
\eta=\frac{N_{1}-N_{2}}{N_{1}} \times 100 \%
$$

where $N_{1}$ and $N_{2}$ are the number of colonies developed on the control and experimental plates, respectively.

Statistical study. Karl Pearson's coefficient of correlation was used to assess the relationship between the concentration of chitosan and antimicrobial activity. Student's $t$-test was used to assess differences at $\mathrm{p}<0.005$ (Bailey 1995).

\section{RESULTS AND DISCUSSION}

Results showed that there was an increase in antimicrobial activity with increasing chitosan concentration ( $\mathrm{p}<0.005$ ) (Table 1). Even though many cells survived at $1 \%$ chitosan (Fig. 1), the highest concentration of chitosan used inhibited Vibrio vulnificus by $88.8 \pm 14.6 \%$, whereas the same concentration inhibited Vibrio alginolyticus by only $50.8 \pm 19.8 \%$. Major factors believed to contribute to the antimicrobial properties of chitosan are concentration of the chitosan in solution, molecular weight, degree of deacetylation

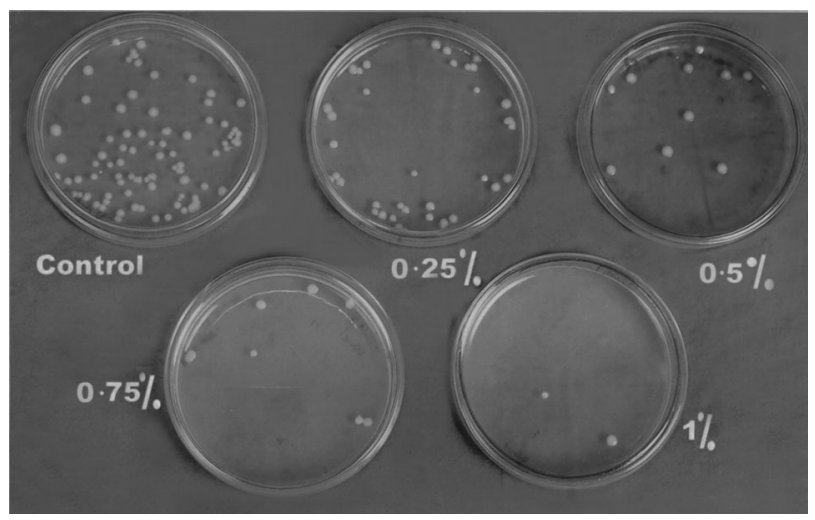

Fig. 1. Effect of different concentrations of chitosan solution on its antimicrobial activity to an isolate of Vibrio

Table 1. Inhibition rate (mean $\pm \mathrm{SD}$ ) of Vibrio isolates to different concentrations of chitosan(w/v). Correlation coefficient is that between concentration of chitosan and cell count of Vibrio

\begin{tabular}{|c|c|c|c|c|c|c|}
\hline Vibrio isolate & $\begin{array}{l}\text { No. of } \\
\text { strains }\end{array}$ & $0.25 \%$ & $0.5 \%$ & $0.75 \%$ & $1.0 \%$ & $\begin{array}{c}\text { Correlation } \\
\text { coefficient }\end{array}$ \\
\hline V. cholerae & 11 & $55.7 \pm 30.8$ & $75.5 \pm 23$ & $81.5 \pm 19.6$ & $85.4 \pm 21.2$ & 0.931 \\
\hline V. parahaemolyticus & 5 & $39.2 \pm 26.3$ & $50.2 \pm 25.8$ & $57.4 \pm 30.8$ & $69.1 \pm 22.3$ & 0.996 \\
\hline V. mediterranei & 6 & $51.1 \pm 27.2$ & $63.7 \pm 26.7$ & $73.9 \pm 20.5$ & $80.4 \pm 19.7$ & 0.990 \\
\hline$V$. nereis & 11 & $63.6 \pm 20.7$ & $73.1 \pm 13.9$ & $81.8 \pm 9.6$ & $84.2 \pm 10.3$ & 0.973 \\
\hline$V$. proteolyticus & 2 & $59 \pm 36.3$ & $65.2 \pm 27.2$ & $72.7 \pm 22$ & $88.1 \pm 12.4$ & 0.975 \\
\hline V. splendidus & 2 & $26.2 \pm 9.8$ & $29.3 \pm 2.8$ & $49.7 \pm 2.7$ & $68.0 \pm 13.7$ & 0.966 \\
\hline V. vulnificus & 3 & $46 \pm 41.2$ & $63 \pm 29.3$ & $80.1 \pm 26.1$ & $88.8 \pm 14.6$ & 0.990 \\
\hline V. alginolyticus & 8 & $21.9 \pm 19.8$ & $29.2 \pm 16.1$ & $41.1 \pm 19.9$ & $50.8 \pm 19.8$ & 0.996 \\
\hline
\end{tabular}


and the level of protonation of the free groups in the chitosan. Using chitosan at different viscosity average molecular weights ranging from less than 5 to $350 \mathrm{kDa}$ on Escherichia coli and Staphylococcus aureus, Zheng \& Zhu (2003) concluded that its antibacterial properties were directly related to its concentration.

Chitosan in the larval rearing system may function as a Vibrio growth depressant. As the risk of infection is directly related to pathogen density, depressed cell counts may help to prevent larval vibriosis. Further, chitosan is recognized as an immunostimulant in fish (Sahoo \& Mukergee 1999, Siwicki et al. 1994); thus, it may also be worthwhile to test it as an immunostimulant in prawn larvae .

Acknowledgements. This work was supported by a grant from the Department of Science and Technology, Government of India (Grant No. SP/SO/C-40/99). We thank Dr. A. Mohandas, Emeritus Professor, CFDDM, CUSAT for editing the manuscript. A.A. and N.S.J. thank DST for fellowship support.

\section{LITERATURE CITED}

Akbuga J (1995) A biopolymer: chitosan. Int J Pharm Adv $1: 3-18$

Allan CR, Hadwiger LA (1979) The fungicidal effect of chitosan on fungi of varying cell wall composition. Exp Mycol 3:285-287

Bailey NTJ (1995) Statistical methods in biology. Cambridge University Press, Cambridge

Bhat SG, Singh ISB (1999) Vibrionaceae associated with larvae and larval rearing systems of Macrobrachium rosenbergii: systematics and pathogenicity. In: Flegel TW (ed) Advances in shrimp biotechnology. National Centre for Genetic Engineering and Biotechnology, Bangkok, p 279

Bojan J (2003) Status of scampi farming in India. Fresh water prawns 2003. College of Fisheries, Kearala Agricultural University, Kochi

Chirkov SN (2002) The antiviral activity of chitosan. Appl

Editorial responsibility: Timothy Flegel,

Bangkok, Thailand
Biochem Microbiol 38:1-8

Delves-Broughton J, Poupard CW (1976) Disease problems of prawn in recirculation systems in UK. Aquaculture $7: 201-217$

Karunasagar I, Pai R, Malathi GR, Karunasagar I (1994) Mass mortality of Penaeus monodon larvae due to antibiotic resistant Vibrio harveyi infection. Aquaculture 128: 203-209

Kendra DF, Hadwiger LA (1984) Characterization of the smallest chitosan oligomer that is maximally antifungal to Fusarium solani and elicits pisatin from Pisum sativum. Exp Mycol 8:276-281

Kubota N (1993) Molecular weight dependence of the properties of chitosan and chitosan hydrogel for use in sustained release drug. Bull Chem Soc Jpn 66:1807-1812

Ravi Kumar MNV (2000) A review of chitin and chitosan applications. React Funct Polym 46:1-27

Roller S, Covill N (1999) The antifungal properties of chitosan in laboratory media and apple juice. Int J Food Microbiol 47:67-77

Sahoo PK, Mukergee SC (1999) Influence of the immunostimulant, chiosan on immune responses of healthy and cortesol treated Rohu (Labeo rohita). J Aquacult Trop 14:209-215

Shepherd R, Reader S, Falshaw A (1997) Chitosan functional properties. Glycoconj J 14:535-542

Sindermann CJ (1977) Disease diagnosis and control in North American marine aquaculture. Elsevier, Amsterdam

Siwicki AK, Anderson DP, Rumsey GL (1994) Dietary intake of immunostimulants by rainbow trout affects nonspecific immunity and protection against furunculosis. Vet Immunol Immunopathol 41:125-139

Sudarshan NR, Hoover DG, Knorr D (1992) Antibacterial action of chitosan. Food Biotechnol 6:257-272

Takahashi Y, Shimoyama Y, Momoyama K (1985) Pathogenicity and characteristics of Vibrio sp. isolated from diseased post larvae of Kuruma prawn, Penaeus japonicus Beta. J Shimonoseki Univ Fish 32:23-31

Tendencia EA, de la Pena LD (2001) Antibiotic resistance of bacteria from shrimp ponds. Aquaculture 195:193-204

Wang GH (1992) Inhibition and inactivation of five species of food borne pathogens by chitosan. J Food Prot 55:916-919

Zheng LY, Zhu JF (2003) Study on antimicrobial activity of chitosan with different molecular weights. Carbohydr Polym 54:527- 530

Submitted: January 12, 2005; Accepted: June 2, 2005

Proofs received from author(s): September 27, 2005 